\title{
Editorial
}

\section{A peste bufônica}

\section{Editorial}

The Buffonic Plague

\author{
Silvia LIEBEL ${ }^{1}$ \\ https://orcid.org/0000-0002-7435-6902 \\ ${ }^{1}$ Editora Chefe de Varia Historia \\ Universidade Federal de Minas Gerais \\ Departamento de História \\ Av. Antônio Carlos 6627, Belo Horizonte, MG, 31.270-901, Brasil \\ liebel.seiziemiste@gmail.com
}

Que diferença faz? Peste ou governador:

o Estado é sempre o Estado. (CAMUS, Estado de Sítio, p.79)

Peste Negra, varíola, cólera, tuberculose, gripe espanhola, tifo. Surtos e epidemias são há muito objetos do ofício historiográfico, em suas mais distintas vertentes. Para muito além da História da Saúde, a História Social, a História Econômica e a História das Sensibilidades, para citar apenas algumas, permitem-nos refletir sobre como as experiências passadas foram vivenciadas, seus efeitos nas ciências e nas artes, os debates acerca das políticas públicas criadas e como as sociedades se reconstruíram. Ainda restam lições a serem aprendidas, como a contínua busca pelo desenvolvimento da empatia, que se revela muito longe de ser um processo evolutivo uniforme e universal. A valorização de algumas vidas em detrimento de outras, precisamente daquelas que se encontram mais vulnerabilizadas, desprovidas do suporte estatal que 
deveria garantir condições dignas de existência à toda a população, denuncia as dificuldades em se compreender o outro como parte de uma mesma humanidade.

É no século XVIII que se observa a difusão de uma linha de pensamento que defendia, precisamente, o bem-estar da humanidade como objetivo último de nossas ações. Mas para se compreender cada um como parte de um mesmo conjunto, habitante de um espaço que deve ser preservado para as gerações futuras, era imperativo romper com o pensamento teleológico impregnado na sociedade que exigia a realização de boas ações para se garantir o reino dos céus. Ao defender uma visão pragmática e racionalista que colocava o desenvolvimento social como chave para a melhoria das condições de vida, neste único mundo que é vivenciável e ao nosso alcance, esse grupo que ulteriormente seria chamado de "radical" lançou as bases para as democracias contemporâneas (Israel, 2002; 2006; 2011; 2020). O apelo da razão e do avanço da ciência enfrentavam então obstáculos que muito lentamente eram esfacelados, obstáculos que permanecem vivos ainda agora, quase três séculos depois. Os regimes monárquicos podem ter caído em grande parte do mundo, mas o narcisista pensamento autocrático ronda governos mais preocupados com sua própria manutenção do que com o serviço público.

Em um momento em que o investimento em ciência se mostra essencial, as escolhas políticas revelam, mais do que nunca, seu impacto através da sociedade. Seja através de pesquisas acerca da estrutura e proliferação de um vírus, da busca pela preservação da vida ou da formação de uma consciência crítica, que nos advirta dos erros outrora cometidos, a academia persiste na busca pelo bem-estar da humanidade. A ciência feita nas universidades públicas e gratuitas mostra espetacularmente seu compromisso com a sociedade, persistindo a despeito de ameaças e cortes. Trata-se de um compromisso com um bem maior, não da caridade pontual de instituições privadas. Pois sem humanidade, não há sentido na preservação da economia.

A necessidade do reforço dos investimentos no campo científico não deveria, no entanto, ser constatada apenas quando sua urgência é manifesta. Ao reforçarmos a base da ciência - com a compreensão de 
que a ciência vai além do campo exato dos números - a sociedade se beneficia como um todo, estando menos sujeita a engodos e charlatanismos. Um investimento geral nas ciências deve também contribuir para as discussões em torno da ética, da valorização da vida (independente de idade, gênero, raça ou classe social), do que implica o desenvolvimento e o futuro da humanidade. Sem reflexão, a ciência é meramente técnica, e a técnica é fria ao determinar quem merece viver e quem deve morrer.

A carência de investimentos se conjuga na atualidade com necessidades palpáveis da população, que se defronta com a recusa de algumas lideranças em se enfrentar o inevitável e com a criação de teorias conspiratórias. Reflexo, como caracteriza D’Ancona, "do valor declinante da verdade como moeda de reserva da sociedade e a difusão contagiosa do relativismo pernicioso disfarçado de ceticismo legítimo" (D’Ancona, 2018, p.14). Negar a razão e a ciência não é uma novidade. Quando os avanços são vistos como ameaças, recorre-se ao intangível, a jejuns e preces contra os males disseminados. No entanto, o apego a dogmas e a tacanha recusa em seguir protocolos baseados em pesquisa científica, nas evidências anunciadas, nos números que aumentam exponencialmente a cada dia, infelizmente não afetam apenas quem se apega a quimeras. A ignorância como instrumento político avança como a própria peste que, na peça de Camus, decreta: "Glória aos estúpidos, pois eles preparam o meu caminho! Eles fazem minha força e minha esperança!" (Camus, 2018, p.190).

Contudo, mesmo que o legado daquele grupo de pensadores que almejava romper as barreiras da ignorância e da superstição tenha sido silenciado, é inegável o avanço alcançado pela razão e pela ciência. Ao contrário do pensamento monolítico, elas avançam. Aprendem com seus erros, voltam atrás e refazem seus passos. Melhoram. Inevitavelmente apontam o melhor caminho a seguir. Em Estado de sítio, a peste enfim abandona seu cerco inclemente quando um único morador de Cádiz perde o medo e a enfrenta. Pestes passam. E costumam ser seguidas por um período de reflexão e renovação, de abundância e ênfase na capacidade humana, mas não sem numerosas perdas que tornam a reflexão ao mesmo tempo corajosa e melancólica. Pestes passam. Governantes também. 


\begin{abstract}
$\approx$
Varia Historia traz a público seu número 71 em meio a um cenário atípico, com pesquisadoras/es e equipes editorais afastadas/os de sala de aula, mas nem por isso deixando a produção de lado - com todos os desafios que o trabalho intelectual apresenta em meio ao isolamento resultante de uma pandemia. O dossiê "História econômica, política e intelectual da África ocidental: lógicas de intercâmbio entre os séculos XV e XIX", organizado por Thiago Mota e Idrissa Ba, inaugura na revista o sistema de dossiês por edital. A proposta reúne autoras e autores de diferentes instituições e nacionalidades, contribuindo para o fortalecimento da área na academia brasileira. A seção de artigos livres conta com textos de Claudio DeNipoti, acerca dos embates em torno da tradução em Portugal no século XVIII; de Simone Kropf, que estuda o fomento aos intercâmbios acadêmicos entre Brasil e Estados Unidos na primeira metade do século XX; e de Gabriel Passetti que, em artigo de sobre a resistência maori aos invasores britânicos no século XIX, mostra as estratégias discursivas empregadas - tanto para, de uma lado, sobreviver, quanto para de outro apelar à barbárie de sujeitos que precisavam ser submetidos - e como a vida humana não estava acima do lucro para o Império. Fecham o número resenhas de Ronaldo Vainfas sobre obra que apresenta os impactos da II Guerra no Nordeste brasileiro, e de Gabriel Guimarães acerca dos movimentos identitários que ascendem na Europa. Apresentando diferentes facetas do ofício historiográfico, esses textos são frutos de trocas acadêmicas e da persistência na entrega ao campo científico, a despeito de todas as forças contrárias.
\end{abstract}

\title{
REFERÊNCIAS BIBLIOGRÁFICAS
}

CAMUS, Albert. Estado de sítio. Rio de Janeiro: Record, 2018.

D'ANCONA, Matthew. Pós-Verdade: a nova guerra contra os fatos em tempos de Fake News. Barueri: Faro Editorial, 2018.

ISRAEL, Jonathan. Democratic Enlightenment: Philosophy, Revolution, and the Human Rights. Oxford: Oxford University Press, 2011. 
ISRAEL, Jonathan. Enlightenment Contested. Philosophy, Modernity, and the Emancipation of Man, 1670-1752. Oxford: Oxford University Press, 2006. ISRAEL, Jonathan. The Enlightenment that Failed. Ideas, Revolution, and Democratic Defeat, 1748-1830. Oxford: Oxford University Press, 2020. ISRAEL, Jonathan. Radical Enlightenment: Philosophy and the Making of Modernity 1650-1750. Oxford: Oxford University Press, 2002. 